\title{
Pengembangan Instrumen Persepsi Pasien Kanker dengan Kemoterapi terhadap Perilaku Caring Perawat: Pilot Study
}

\author{
Yulta Kadang1, Ariyanti Saleh², Kusrini Kadar ${ }^{3}$ \\ ${ }^{1}$ Akademi Keperawatan Justitia Palu \\ ${ }^{2,3}$ Fakultas Keperawatan, Universitas Hasanuddin Makassar
}

\section{Info Artikel \\ Riwayat Artikel: \\ Received : 04 Desember 2021 \\ Revised : 19 Desember 2021 \\ Accepted : 28 Desember 2021}

\section{Kata Kunci:}

Pasien Kanker

Kemoterapi

Pilot Study

Pengembangan Kuesioner

\begin{abstract}
ABSTRAK
Latar Belakang: Perawat memiliki peran yang sangat penting dalam memberikan informasi yang meliputi pengetahuan tentang kemoterapi dan mampu menjelaskan apa yang akan terjadi selama pasien menerima kemoterapi, termasuk kemungkinan efek samping dan penanganannya. Salah satu ukuran yang dapat digunakan untuk mengukur perilaku caring perawat adalah kuesioner. Pengembangan kuesioner mempertimbangkan struktur dan isi kuesioner dan saran dari para ahli. Penelitian lain juga menginformasikan bahwa uji coba sering dilakukan untuk menguji kelayakan teknik, metode, kuesioner, wawancara dan bagaimana metode tersebut berfungsi bersama dalam konteks tertentu. Tujuan: Untuk menguji instrumen (kuesioner) yang telah dikembangkan oleh peneliti, sebelum dilakukan uji validitas dan reliabilitas. Metode: Penelitian ini merupakan penelitian cross sectional, dimana instrumen yang akan diuji didistribusikan kepada 30 pasien kanker yang menjalani kemoterapi di RS Stella Maris Makassar. Pemilihan sampel penelitian menggunakan metode non probability sampling, dengan teknik purposive sampling. Hasil: Temuan penelitian berdasarkan hasil pilot study, mayoritas responden memahami butir-butir pernyataan yang terdapat dalam instrumen (kuesioner). Namun pada kolom saran/komentar yang disediakan, beberapa responden berkomentar bahwa ada 6 item pernyataan yang maknanya tidak dipahami oleh responden saat mengisi instrumen. Berdasarkan komentar dari responden dan dengan mempertimbangkan rekomendasi dari beberapa panel ahli metode Delphi pada langkah kedua, peneliti memutuskan untuk mengubah item pernyataan yang menggunakan kalimat negatif menjadi kalimat positif. Kesimpulan: Hasil akhir instrumen setelah direvisi berjumlah 27 item pernyataan. Tidak ada item pernyataan yang ditambahkan atau dikurangi. Namun peneliti merevisi 6 item pernyataan sebelumnya yang negatif, sehingga hasil akhir dari uji coba ini adalah keseluruhan item pernyataan pada instrumen ini adalah item pernyataan yang bermakna positif.
\end{abstract}

This is an open access article under the CC BY-SA license.

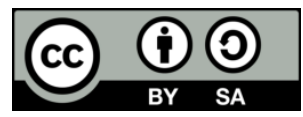

\section{Corresponding Author:}

Yulta Kadang,

Prodi DIII Keperawatan, Akademi Keperawatan Justitia Palu,

Jl Vatu Gusu, Palu, Indonesia

Email: yultakadang90@gmail.com/ Phone: 082150824338

\section{PENDAHULUAN}

Kemoterapi merupakan pengobatan kanker utama yang menyebabkan banyak efek samping fisik dan masalah psikologis seperti insomnia, kecemasan dan depresi (Ummavathy et al., 2017; Black \& Hawks, 2014; Stuart, 2013). Perawat sebagai anggota medis inti dalam tim perawatan sangat penting untuk mengetahui seberapa tepat mereka dapat menilai kebutuhan dan gejala pasien mereka untuk memberikan perawatan kanker berkualitas tinggi (Nakaguchi et al., 2013). Perawat kanker perlu mengembangkan strategi yang efektif untuk membantu pasien dan keluarga mereka dengan beban emosional dan kecemasan sebelum dan selama kemoterapi, menginformasikan pasien dan keluarga mereka tentang efek samping yang diharapkan, memantau efek samping dan toksisitas pengobatan, dan meningkatkan kepatuhan pasien terhadap pengobatan (Bayram et al., 2014). Kualitas hubungan dapat menjadi terapi bagi pasien dan dimulai dari kesiapan perawat untuk berhubungan dengan pasiennya dengan menunjukkan sikap keterbukaan, penerimaan, dan kepedulian (Markides, 2011). 
Oleh karena itu, caring perawat merupakan inti dari keperawatan yang merupakan faktor dasar yang membedakan perawat dengan profesi kesehatan lainnya. Dalam pendekatan yang berpusat pada pasien, pasien terlibat aktif dalam perawatannya, termasuk pasien juga berhak menilai perilaku caring Perawat melalui persepsi pasien (Barry \& Edgman-Levitan, 2012; Papastavrou et al., 2012). Penilaian berkelanjutan terhadap pasien yang menerima kemoterapi sering dilakukan dalam berbagai pengaturan dan cara, bervariasi dari pengaturan klinis yang lebih formal di rumah sakit hingga komunitas atau melalui telepon (Lennan et al., 2012). Salah satu ukuran yang dapat digunakan untuk mengukur perilaku caring perawat adalah kuesioner.

Pengembangan kuesioner mempertimbangkan struktur dan isi kuesioner dan saran dari para ahli di bidangnya, serta hasil uji coba atau pengujian ulang (pilot study) (Timmins, 2015). Jika kuesioner tidak diuji, risikonya dapat secara langsung menyebabkan masalah selama fase pengumpulan data, dan tidak ada peluang untuk mengatasi masalah ini sebelum studi utama. Anda dapat menemukan bahwa satu pertanyaan tidak berfungsi, dengan peserta tidak menjawab pertanyaan atau menjawabnya dengan salah. Jenis masalah ini dapat diselesaikan dengan cepat dan sederhana pada tahap pilot study (Timmins, 2015). Oleh karena itu, beberapa peneliti menyarankan bahwa pengujian merupakan langkah penting dalam desain kuesioner, sejauh memenuhi harapan (Coughlan et al 2013). Penelitian lain juga menginformasikan bahwa uji coba/pilot study sering dilakukan untuk menguji kelayakan teknik, metode, kuesioner, wawancara dan bagaimana metode tersebut berfungsi bersama dalam konteks tertentu (Doody \& Doody, 2015). Oleh karena itu, penelitian ini bertujuan untuk menguji instrumen (kuesioner) yang telah dikembangkan oleh peneliti melalui tahap pilot study sebelum dilakukan uji validitas dan reliabilitas terhadap kuesioner.

\section{METODE PENELITIAN}

Desain Penelitian yang digunakan dalam penelitian ini adalah Design and Development Research (perancangan dan penelitian pengembangan) dimana desain ini merupakan kajian sistematis untuk meneliti, merancang, memproduksi dan menguji validitas produk yang telah dihasilkan (Sugiyono, 2015). Berdasarkan Caring Theory Swanson, dilakukan pengembangan instrumen. Setelah melalui tahap kualitatif hingga membentuk kerangka konseptual baru dan tahap uji ahli menggunakan metode Delphi mencapai butir kesepakatan dalam angket, kemudian dilakukan pilot study sebagai tahap ketiga dalam pengembangan instrumen. Kuesioner penting untuk diujicobakan sebelum diimplementasikan dengan peserta penelitian, untuk memastikan objektivitas dan kejelasan kuesioner dan untuk mengurangi risiko yang terkait dengan desain penelitian (Massaroli et al., 2017; Moore et al., 2011).

Pada penelitian ini dilakukan tahap ketiga pilot study, dimana pilot study digunakan untuk menguji coba instrumen yang telah dikambangkan. Setelah masing-masing kuesioner diuraikan, yang sama diajukan untuk uji coba sebelum diimplementasikan dengan peserta penelitian, untuk memastikan objektivitas dan kejelasan kuesioner (Massaroli et al., 2017). Instrumen yang akan diuji didistribusikan kepada 30 pasien kanker yang menjalani kemoterapi di RS Stella Maris Makassar, selama bulan November 2019. Rea \& Parker (2014) menetapkan jumlah responden dalam studi percontohan adalah 20 sampai 40 responden. Sampel penelitian dipilih dengan menggunakan metode non-probability sampling yaitu purposive sampling, yaitu pemilihan sampel yang ditentukan berdasarkan tujuan penelitian. Pemilihan sampel dilakukan dengan sengaja karena memiliki pengalaman yang sesuai dengan fenomena yang diteliti. Penelitian dilakukan setelah mendapat Persetujuan Etik dari Komite Etik Penelitian Kesehatan Fakultas Kedokteran Universitas Hasanuddin (Etik No. 1114/UN4.6.4.5.31/PP36/2019).

Sebelum melakukan pilot study, peneliti terlebih dahulu meminta persetujuan responden dengan menjelaskan tujuan penelitian dalam bentuk informed consent. Sejalan dengan penelitian sebelumnya yang menjelaskan bahwa dasar pemilihan sampel harus diperjelas agar responden mengerti bahwa tidak ada agenda atau motivasi tersembunyi yang tidak terungkap di balik kuesioner (Rea \& Parker, 2014).

Pada awal pengembangan instrumen, tahap kualitatif menghasilkan angket dengan 5 domain utama dan 33 item pernyataan. Kemudian dilanjutkan tahap metode delphi dimana metode ini dilaksanakan dengan cara penilaian suatu produk oleh para kelompok ahli dengan tujuan membuat keputusan, menilai prioritas atau membuat prakiraan (Keeney, Hasson, \& McKenna, 2011). Setelah melalui tahap metode delphi dan mencapai kesepakatan ahli secara keseluruhan, item pernyataan yang tersisa adalah 27 item pernyataan. Dan pada tahap pilot study ini instrumen yang akan diujikan terdiri dari 5 domain utama dan 27 item pernyataan. 


\section{HASIL}

\subsection{Karakteristik Responden}

Tabel 1. Karakteristik Responden

\begin{tabular}{|c|c|c|}
\hline Karakteristik & $n$ & $\%$ \\
\hline \multicolumn{3}{|l|}{ Jenis Kelamin } \\
\hline Laki-laki & 29 & 96.7 \\
\hline Perempuan & 1 & 3.3 \\
\hline Total & 30 & 100 \\
\hline \multicolumn{3}{|l|}{ Umur } \\
\hline 26-35 Tahun & 1 & 3.3 \\
\hline 36-45 Tahun & 5 & 16.7 \\
\hline 46-55 Tahun & 12 & 40.0 \\
\hline 56-65 Tahun & 11 & 36.7 \\
\hline$>65 \quad$ Tahun & 1 & 3.3 \\
\hline Total & 30 & 100 \\
\hline \multicolumn{3}{|l|}{ Agama } \\
\hline Islam & 17 & 56.7 \\
\hline Protestan & 8 & 26.6 \\
\hline Katolik & 5 & 16.7 \\
\hline Total & 30 & 100 \\
\hline \multicolumn{3}{|l|}{ Pendidikan } \\
\hline $\mathrm{SD}$ & 11 & 36.7 \\
\hline SMP & 6 & 20 \\
\hline SMA & 11 & 36.6 \\
\hline $\mathrm{S} 1$ & 2 & 6.7 \\
\hline Total & 30 & 100 \\
\hline \multicolumn{3}{|l|}{ Pekerjaan } \\
\hline IRT & 18 & 60.0 \\
\hline Wiraswasta & 5 & 16.8 \\
\hline Petani & 1 & 3.3 \\
\hline Swasta & 4 & 13.3 \\
\hline PNS & 1 & 3.3 \\
\hline Pensiunan & 1 & 3.3 \\
\hline Total & 30 & 100 \\
\hline
\end{tabular}

Tabel 1 di atas menunjukkan distribusi frekuensi dan persentase responden berdasarkan karakteristik jenis kelamin, umur, agama, pendidikan dan pekerjaan dengan jumlah $(n=30)$.

\subsection{Pelaksanaan Pilot Study}

Ada 30 responden $(n=30)$ yang terlibat dalam pelaksanaan pilot study. Rancangan instrumen diberikan kepada responden kemudian responden diminta untuk menilai setiap butir pernyataan dalam rancangan instrumen dengan menjawab beberapa poin, yaitu: kejelasan kuesioner, panjang kuesioner, kesulitan pengisian kuesioner, struktur dan format kuesioner. daftar pertanyaan. Responden juga diminta untuk memberikan komentar jika ada masukan untuk perbaikan instrumen. Berikut adalah hasil dari pilot study tersebut:

Tabel 2. Hasil Pertanyaan Pilot Studi

\begin{tabular}{ccc}
\hline Hasil Pilot Studi & \multicolumn{2}{c}{ Total Responden } \\
\cline { 2 - 3 } Lamanya waktu untuk mengisi kuesioner & $\%$ \\
<5 Menit & 6 & 20 \\
5-10 Menit & 24 & 80 \\
Panjang Kuesioner & & \\
Sangat Pendek & 0 & 0 \\
Sudah Baik & 23 & 76.7 \\
Sangat Panjang & 7 & 23.3 \\
\hline
\end{tabular}




\begin{tabular}{ccc}
\hline Kejelasan Kuesioner & & \\
Sangat Jelas & 11 & 36.7 \\
Jelas & 12 & 40.0 \\
Cukup Jelas & 7 & 23.3 \\
Tidak Jelas & - & - \\
Struktur dan Format Kuesioner & \\
Sangat Baik & 23 & 76.7 \\
Baik & 7 & 23.3 \\
Cukup Baik & - & - \\
Tidak Baik & - & - \\
Kesulitan Mengisi Kuesioner & & \\
Ya & 7 & 23.3 \\
Tidak & 23 & 76.7 \\
\hline
\end{tabular}

Berdasarkan tabel 2 di atas, dapat dijelaskan bahwa dari pertanyaan pilot study tentang kejelasan instrumen diperoleh data bahwa dari 30 responden yang menjawab, 11 (36.7\%) responden menjawab bahwa instrumen yang dikembangkan sangat jelas, 12 (40.0\%) responden menjawab dengan jelas dan $7(23.3 \%)$ responden menjawab cukup jelas. Pertanyaan pilot study selanjutnya yaitu tentang panjang instrumen diperoleh data bahwa dari 30 responden yang menjawab, 23 (76.7\%) responden menjawab panjang kuesioner baik, $7(23.3 \%)$ responden menjawab instrumen terlalu panjang dan tidak ada responden yang menjawab instrumen terlalu singkat. Pertanyaan pilot study tentang struktur dan format instrumen diperoleh data bahwa dari 30 responden yang menjawab, $23(76.7 \%)$ responden menjawab bahwa struktur dan format angket sangat baik, 7 (23.3\%) responden menjawab baik, dan tidak ada responden yang menjawab cukup dan kurang baik. Pertanyaan pilot study tentang kesulitan dalam pengisian kuesioner, diperoleh data bahwa dari 30 responden yang menjawab, $23(76.7 \%)$ responden menjawab tidak mengalami kesulitan saat mengisi instrumen dan 7 (23.3\%) responden menjawab kesulitan saat mengisi instrumen.

Pada saat pengisian kuesioner peneliti juga melakukan observasi dan menghitung lamanya waktu yang dibutuhkan responden dalam pengisian kuesioner, sehingga diperoleh data bahwa dari 30 responden yang telah menjawab, $24(80 \%)$ responden membutuhkan waktu $<5$ menit untuk mengisi instrumen dan 7 $(20 \%)$ responden lainnya membutuhkan waktu 5-10 menit untuk mengisi instrumen.

Di kolom saran/ komentar yang telah disediakan, beberapa responden memberikan komentar bahwa ada 6 item pernyataan, yaitu item pernyataan yang menggunakan kalimat negatif yang maknanya kurang dipahami oleh responden pada saat mengisi instrumen tersebut. Responden 5 mengatakan bahwa "pertanyaannya terbalik-balik jadi sangat membingungkan untuk di isi". Sedangkan responden 13 mengatakan bahwa "saya susah mengerti dengan nomor pernyataan yang ada kata tidaknya". Adapun 6 item pernyataan yang menggunakan item negatif, dapat dilihat pada tabel 3 di bawah ini:

Tabel 3 item pernyataan yang menggunakan kalimat negatif

\section{Negative Item}

Number of Item

1. Perawat tidak memperkenalkan diri kepada pasien atau keluarga terlebih dahulu sebelum melaksanakan kemoterapi / tindakan lainnya.

2. Perawat tidak menanyakan keluhan pasien terkait efek kemoterapi selama periode kemoterapi dilaksanakan

3. Perawat tidak memiliki pengetahuan yang baik ketika memberikan penjelasan tentang pelaksanaan kemoterapi kepada pasien / keluarga

4. Perawat tidak menanyakan kesiapan pasien terlebih dahulu ketika akan melakukan tindakan keperawatan selama periode kemoterapi dilaksanakan

5. Perawat tidak menggunakan alat pelindung diri (masker dan sarung tangan) untuk mencegah penyebaran infeksi kepada pasien dan melindungi diri perawat ketika periode kemoterapi dilaksanakan

6. Perawat tidak menghargai adat atau kebiasaan adat atau kebiasaan yang diyakini pasien tentang penyakit dan pengobatan selama periode kemoterapi dilaksanakan

Berdasarkan tabel 3 di atas, item pernyataan yang memiliki makna negatif berjumlah 6 item yaitu: item nomor 1, 7, 12, 14, 16 dan 25. Berdasarkan komentar dari responden serta mempertimbangkan saran beberapa panel ahli pada metode delphi pada tahap dua, maka peneliti memutuskan untuk mengubah item pernyataan yang menggunakan kalimat negatif menjadi kalimat positif. Untuk melihat hasil akhir perbaikan item pernyataan setelah dilakukan pilot study, dapat dilihat pada tabel 4 berikut ini: 
Tabel 4 perbaikan item pernyataan menggunakan kalimat positif

1. Perawat memperkenalkan diri kepada pasien atau keluarga terlebih dahulu sebelum melaksanakan kemoterapi / tindakan lainnya

2. Perawat menjelaskan tentang tujuan pelaksanaan kemoterapi secara rinci dan jelas kepada pasien atau keluarga sebelum memulai periode kemoterapi

3. Perawat menjelaskan tentang jenis dan cara pemberian obat kemoterapi kepada pasien atau keluarga secara rinci dan jelas sebelum memulai periode kemoterapi

4. Perawat menjelaskan tentang jenis dan cara pemberian obat kemoterapi kepada pasien atau keluarga secara rinci dan jelas sebelum memulai periode kemoterapi

5. Perawat menjalin komunikasi yang baik kepada pasien atau keluarga selama periode kemoterapi dilaksanakan

6. Perawat bersedia menjawab pertanyaan pasien atau keluarga dengan sopan dan ramah selama periode kemoterapi dilaksanakan

Berdasarkan tabel 4 di atas, 6 item pernyataan yang awalnya memiliki makna negatif telah diubah oleh peneliti menjadi item pernyataan positif. Sehingga 27 item pernyataan di dalam instrumen semuanya menggunakan pernyataan dengan makna positif.

\section{DISKUSI}

Pada tahap ini, uji coba (pilot study) dilakukan oleh peneliti dengan meminta 30 responden untuk membaca seluruh item pernyataan dalam instrumen dan memberikan penilaian terhadap instrumen secara keseluruhan dengan menjawab beberapa pertanyaan dalam format pilot study yang telah dibuat. Penelitian sebelumnya menjelaskan bahwa uji coba ( pilot study) juga dapat digunakan dalam penelitian dimana penulis merencanakan instrumen survei yang dirancang sendiri, kemudian melihat seberapa baik desain tersebut akan berfungsi saat digunakan (Avella, 2016). Percobaan tidak dilakukan untuk menguji hipotesis atau untuk mengevaluasi keamanan efikasi dan efektivitas. Oleh karena itu, studi kelayakan dan uji coba tidak memiliki ukuran sampel yang besar (Thabane et al., 2010). Untuk mengetahui apakah instrumen yang telah dirancang oleh peneliti berfungsi dengan baik, peneliti membuat beberapa pertanyaan yang akan dijawab oleh responden dalam melakukan penilaian terhadap instrumen tersebut. Beberapa pertanyaan yang diberikan yaitu: kejelasan instrumen, panjang instrumen, struktur dan format instrumen, kesulitan menjawab instrumen dan lamanya waktu yang dibutuhkan untuk menjawab butir-butir pernyataan yang terdapat dalam instrumen.

Pada pertanyaan pilot study tentang kejelasan instrumen, 11 (36,7\%) responden menjawab sangat jelas, $12(40 \%)$ responden menjawab dengan jelas dan $7(23,3 \%)$ responden menjawab cukup jelas. Berdasarkan data tersebut, sebagian besar responden berpendapat bahwa butir-butir pernyataan yang terdapat dalam instrumen sudah jelas. Rea \& Parker (2014) mengatakan bahwa instrumen yang dikembangkan harus sejelas mungkin dengan tetap mencakup berbagai konten yang dibutuhkan dalam penelitian ini. Peneliti harus berhati-hati untuk mengembangkan pertanyaan yang mungkin menarik tetapi tidak sesuai atau tidak berhubungan dengan fokus utama tujuan penelitian. Pertanyaan pilot study selanjutnya adalah tentang panjang instrumen, sebagian besar responden yaitu $23(76,7 \%)$ responden berpendapat bahwa panjang kuesioner sudah baik. Tujuan dari pertanyaan uji coba ini berkenaan dengan panjangnya kuesioner adalah untuk memastikan bahwa kuesioner tidak terlalu panjang dan rumit bagi responden sehingga menyebabkan keengganan responden untuk melengkapi instrumen survei, sehingga membahayakan tingkat respon (Rea \& Parker, 2014). Pertanyaan pilot study tentang struktur dan format instrumen diperoleh data bahwa dari 30 responden yang menjawab sebagian besar responden yaitu $23(76,7 \%)$ responden menjawab bahwa struktur dan format kuesioner sangat baik. Penelitian sebelumnya menjelaskan bahwa instrumen yang tidak terorganisir dengan baik dapat membingungkan responden, mendapatkan tanggapan yang bias dari responden, dan membahayakan kualitas upaya penelitian secara keseluruhan (Rea \& Parker, 2014). Oleh karena itu, dalam membuat instrumen penelitian, pertanyaan pertama harus berkaitan dengan masalah yang dikemukakan dalam pendahuluan tetapi harus relatif mudah dijawab. Pertanyaan pengantar harus mendapatkan pendapat langsung atau tidak rumit atau mendapatkan informasi faktual dasar tetapi tidak terlalu sensitif lagi, seperti percakapan. Tujuan utama dari pertanyaan awal adalah untuk merangsang minat untuk melanjutkan kuesioner tanpa menyinggung, mengancam, membingungkan, atau membosankan responden. Dua pertanyaan pertama bersifat fundamental dan faktual. Pertanyaan ketiga, meskipun menimbulkan pendapat, tetapi tidak rumit. Pada pertanyaan pilot study selanjutnya tentang kesulitan dalam pengisian instrumen diperoleh data bahwa dari 30 responden yang menjawab mayoritas responden yaitu 23 $(76,7 \%)$ responden menjawab tidak mengalami kesulitan dalam pengisian instrumen. Peneliti memastikan 
bahwa responden memahami pertanyaan dengan cukup baik untuk memberikan representasi akurat dari pendapat, perilaku, dan karakteristik mereka untuk tujuan penelitian (Rea \& Parker, 2014). Pada saat pengisian kuesioner, peneliti mengamati dan menghitung setiap waktu yang dibutuhkan oleh responden dalam mengisi kuesioner. Setelah dilakukan akumulasi diperoleh data bahwa dari 30 responden yang telah mengisi angket, mayoritas responden $24(80 \%)$ responden menjawab butuh waktu $<5$ menit untuk mengisi instrumen dan 7 (20\%) responden lainnya menjawab butuh waktu 5-10 menit untuk mengisi instrumen. Pada penelitian sebelumnya merekomendasikan bahwa waktu yang digunakan untuk wawancara langsung dengan pilot study tidak lebih dari 30 menit (Rea \& Parker, 2014). Penelitian terbaru juga merekomendasikan bahwa waktu yang dibutuhkan responden untuk menyelesaikan pertanyaan pilot study adalah sekitar 20 menit (Fraser et al., 2018).

Penelitian pilot study ini sangat penting dalam mendeteksi permasalahan yang berkaitan dengan bahasa. Pertanyaan yang membingungkan menghasilkan perasaan tidak pasti pada diri responden sebagai maksud atau makna pertanyaan. (Rea \& Parker, 2014). Setelah uji coba (pilot study), peneliti harus merevisi pernyataan dalam kuesioner sesuai kebutuhan. Umpan balik yang diberikan oleh peserta tentang item awal dan kuesioner dianalisis. Jika ada konsensus bahwa item tertentu tidak jelas atau kontroversial, item tersebut harus dihapus atau diubah untuk pertanyaan berikutnya

\section{KESIMPULAN}

Penelitian ini merupakan tahap pilot study. Pada tahap ini, instrumen akhir yang dihasilkan berjumlah 27 item pernyataan. Tidak ada item pernyataan yang ditambahkan atau dikurangi. Namun peneliti merevisi 6 item pernyataan sebelumnya yang negatif, sehingga hasil akhir dari uji coba ini adalah keseluruhan item pernyataan pada instrumen ini adalah item pernyataan yang bermakna positif.

\section{UCAPAN TERIMA KASIH}

Penulis mengucapkan terima kasih kepada pasien kanker yang sedang menjalani kemoterapi di RS Stella Maris Makassar yang telah bersedia menjadi responden dalam penelitian ini, juga kepada seluruh perawat kanker di Rumah Sakit Stella Maris Makassar yang telah membantu dalam penelitian, khususnya kepada Christian Delchky Youfans yang telah bersedia menjadi Asisten peneliti.

\section{REFERENSI}

Avella,J.R. (2016). Delphi panels: Research design, procedures, advantages, and challenges. International Journal of Doctoral Studies, 11:305-321. retrieved from http://www.informingscience.org/Publications/3561.

Bayram, Z., Durna, Z., Akin,S. (2014). Quality of life during chemotherapy and satisfaction with nursing in Turkish breast cancer patients. European Journal of Cancer Care. 23, 675-684. doi: 10.1111/ecc.12185.

Black, J.M., Hawks, J.H. (2014). Surgical Medical Nursing (Clinical Management for Expected Results). (Nampira R, Penerjemah.).(8rd ed.). Jakarta: Salemba Emban Patria.

Conn,V.S., Algase, D.L., Rawl, SM., Zerwic, JJ., Wyman, J.F. (2010). Publishing pilot intervention work. Western Journal of Nursing Research, 32(8), 994-1010. doi: 10.1177 / 0193945910367229.

Coughlan, M., Cronin, P., Ryan, F. (2013). Step-by-step inquiry to critiquing research. Part 1: quantitative research. $\mathrm{Br} \mathrm{J}$ Nurs, 16(11), 658-663. doi:10,12968 / bjon.2007.16.11.23681

Doody, O., Doody, C.M., (2015). Conducting a pilot study: case study of a novie researcher. British Journal of Nursing, 24(21),1074-1078. doi:10,12968 / bjon.2015.24.21.1074.

Fraser, J., Fahlman, D., Arscott, J., Guillot, I. (2018). Pilot testing for feasibility in a study of student retention and attrition in online undergraduate programs. International Review of Research in Open and Distributed Learning, 19(1). retrieved fromhttps://files.eric.ed.gov/fulltext/EJ1174051.pdf.

Jozsa, K., \& Morgan, G.A. (2017). Reserved items in likert scales: filtering out invalid responders. Journal of Psychological and Educational Research, 25(1):7-25. retrieved from:https://www.researchgate.net/publication/317264817_Reversed_Items_in_Likert_Scales_Filtering_Out_Invali d_Responders.

Keeney, S., Hasson, F., \& McKenna, H. (2011). The Delphi Technique in Nursing and Health Research (First). United Kingdom: Wiley-Blackwell.

Markides, M. (2011). The important of Good Communication between patient and health professionals. J Pediatr Hematol Oncol, 33(2), 123-125. doi:10.1097 / MPH.0b013e318230e1e5.

Massaroli, A., Martini, G.J., Lino, M.M., Spenassato, D., Massaroli, R. (2017). The Delphi method as a methodological framework for research in nursing. Texto \& Contexto-Enfermagem,26 (4). Doi: http://dx.doi.org/10.1590/010407072017001110017.

Michael, J., Barry, M.J., Edgman-Levitan S. (2012). Shared decision making. The pinnacle of patient-centered care. The New England Journal of Medicines, 366 (9), 780-781. doi:10.1056 / NEJMp1109283. 
Moore, C.G., Carter, R.E., Nietert, P.J., Stewart, P.W. (2011) Recommendations for planning pilot studies in clinical and translational research. Clinical and Translational Science, 4(5), 332-337. doi:10.1111 / j.1752-8062.2011.00347.x.

Nakaguchi, T., Okuyama, T., Uchida, M., Ito, Y., Komatsu, H., Wada M, Akechi T. (2013). Oncology nurses' recognition of their patients undergoing chemotherapy. Japanese Journal of Clinical Oncology, 43(4),369-376. doi:https://doi.org/10.1093/jico/hyt003.

Papastavrou., Efstathiou, G., Tsangari, H., Suhonen, R., Leino-Kilpi, H., Patiraki, E., \& Merkouris, A. A. (2012). crosscultural study of the concept of caring through behavior: Patients 'and nurses' perspectives in perspective six different EU countries. Journal of Advanced Nursing, 8(5), 1026-1037.doi: 10.1111 / j.1365-2648.2011.05807.x.

Periasamy, P., Sidik, M.S., Rampai, L., Fadhilah, I.S., Zavare, A.M., Mahmud, R.(2017). Effects of chemotherapy counseling by pharmacists on quality of life and psychological outcomes of oncology patients in Malaysia: a randomized control trial. Health and Quality of Life Outcomes, 15(1), 104. doi: 10.1186 / s12955-017-0680-2.

Rea, L.M., \& Parker, R. A. (2014). Designing and conducting survey research: a comprehensive guide. (4th ed.). San Francisco: JOSSEY-BASS.

Robinson, M.A. (2017). Using multi-item psychometric scales for research and practice in human resource management. Human Resource Management,57(3),739-750. doi:https://doi.org/10.1002/hrm.21852

Stuart, G.W. (2013). The Book of Psychiatric Nursing. (10rd ed.). Jakarta: EGC; 2013.

Sugiyono. (2015). Metode Penelitian \& Pengembangan: Research and Development. Bandung: Alfabeta.

Thabane, L., Ma, J., Chu, R., Cheng, J., Ismaila, A., Rios, L.P., Goldsmith, C.H. (2010). A tutorial on pilot studies: The what, why and how. BMC Medical Research Methodology, 10(1). doi: 10.1186 / 1471-2288-10-1.

Timmins, F. (2015). Surveys and questionnaires in nursing research. Art \& Science Research Series, 29(42), 42-50. doi: 10.7748 / ns.29.42.42.e8904. 